\title{
THE BENEFITS FROM THE GREEN INFRASTRUCTURE IN RELATION WITH EMISSION OF SUSPENDED PARTICLES (PM10) WITHIN THE MUNICIPALITY OF TIMIŞOARA
}

\author{
Ionuț Cristian Moale ${ }^{1, *}$, Florian Bodescu ${ }^{1}$ \\ ${ }^{1}$ S.C. MULTIDIMENSION S.R.L., Str. Ciprian Porumbescu, nr. 7, \\ Săveni, Jud. Ialomița, România, Tel/Fax: +40314258424
}

Current Trends in

Natural Sciences

\begin{abstract}
The purpose of the article is to highlight the efficiency of the retention capacity of green infrastructure in reducing PM10 concentrations in the Timisoara agglomeration.

We propose a methodology to highlight the benefits of the green spaces applied at the level of Timişoara agglomeration, in which is used the internal variability of the green spaces (plant species, tree height, tree density) correlated with the spatial analysis of the dispersion of the suspended particle concentrations PM10, to highlight by a theoretical model the absorption/filtration of particles.

Following the calculations, it was estimated that the green infrastructure has a minimum retention capacity of approximately $0.01 \%$ and a maximum of $10.39 \%$ of the concentration of PM10 suspended particles, to which the green infrastructure is exposed. We mention that the article was made using non-confidential data presented in the Air Quality Plan for PM10 proposed in public debate on the website of Timisoara City Hall. Also, the company S.C. MULTIDIMENSION S.R.L. made the Study on air quality in the Timişoara agglomeration, which was the basis for the elaboration of the Air Quality Plan for the PM10 indicator in the Timişoara agglomeration.
\end{abstract}

Keywords: concentrations PM10, green infrastructure, green spaces, retention capacity, suspended particle

\section{INTRODUCTION}

Over the last 20 years, a major concern for urban areas has been the issue of air quality degradation. The increase in the quantities of emissions from different sources of emissions, in principal mobile sources, demonstrates the causality of the degradation (https://www.eea.europa.eu/publications/airquality-in-europe-2019).

In this context, the concept of "green infrastructure" has begun to be increasingly analyzed (Bealey et al, 2006; Benedict and McMahon, 2006; Hewitt et al., 2019), it has a positive effect on air quality (Nowak J.D. et al., 2006), in particular we are focus on suspended particles. The green infrastructure reduces pollution with suspended particles by absorption and filtration of particles (Nowak and Heisler, 2010).

As environmental problems identified in Europe, air pollution represents the biggest risk to human health. As associated effects of air pollution on human health, we can mention: acute respiratory diseases, worsening of chronic respiratory diseases, heart rhythm abnormalities or strokes (especially for elderly people). Whether we are talking about a greater or lesser period of exposure 
to pollutants, the most affected categories of people are: children, pregnant women and the elderly people (https://www.eea.europa.eu/publications/air-quality-in-europe-2019).

As main air pollutants indicators we can list: suspended particles (PM10, PM2.5), sulfur dioxide $\left(\mathrm{SO}_{2}\right)$, nitrogen dioxide $\left(\mathrm{NO}_{2}\right)$, nitrogen oxides (NOx), carbon monoxide $(\mathrm{CO})$, benzene $\left(\mathrm{C}_{6} \mathrm{H}_{6}\right)$ and heavy metals $(\mathrm{Pb}, \mathrm{As}, \mathrm{Cd})$. Suspended particles (PM10, PM2.5) are a mixture of fine particles that originate from both natural sources (volcanic eruptions, sandstorms etc.) and anthropogenic sources (heating systems in residential and commercial areas, road traffic, construction activities etc.).

Also, in urban areas exposed to higher concentrations of PM10, it is important to analyze the particle size due to the influence it can have on the health population, and that particles can go through the airways to the lung alveoli and causing inflammation. As effects of pollution with suspended particles we can mention cough, pain and respiratory difficulties.

According to Order no. 598/2018, Timisoara agglomeration is included in the management regime I for PM10 pollutant (suspended particles with a diameter less than or equal to $10 \mu \mathrm{m}$ ).

Thus, it was necessary to draw up an air quality plan, as a result of exceeding the daily limit values recorded in several years at air quality monitoring stations (for example in 2017 there were 26 exceedances at TM-1 station, 25 exceedances at TM-2 station and 33 exceedances the TM-5 station).

At the level of Timişoara Agglomeration there are two main types of green spaces:

- Parks and green banks along the Bega Canal that runs through the city from east to west

- The Green Forest which is located in the north-eastern part of the city

Also, in the north-western part of the agglomeration, a forest curtain was set up, which is located between the Timişoara - Jimbolia and Calea Aradului roads. In addition to the green spaces mentioned above, there are green spaces between blocks, street alignments, squares and a small number of parks that are clearly delimited (https://www.primariatm.ro/uploads/files/comunicate_net_2019/Plan_calitate_aer_PM10.pdf). According to the U.S. Environmental Protection Agency, trees, parks, and other features of green infrastructure can reduce particulate matter pollution by absorbing and filtering of particles. Also, green infrastructure has benefits in improving air quality, among which we can mention (https://www.epa.gov/green-infrastructure/benefits-green-infrastructure):

- reduction of air temperature

- reduction of emissions from stationary sources

- absorption/filtration of air pollutants like particulate maters

In this respect we are focus on testing a theoretical approach based on modeling of PM10 exposure analyzes to reflect maximum potential retention of green infrastructure components.

\section{MATERIALS AND METHODS}

At the level of Timişoara Agglomeration, the following categories of green spaces from Open Street Map were analyzed:

- Parks - 33.897 ha - they have been selected 8 parks in the central area of the city (Botanical Park, Central Park, Cathedral Park, Justice Park, Civic Park, Children's Park, People's Park, The park next to the Student Complex);

- Street green spaces - 11.861 ha - they have been selected 7 street green spaces in the central area of the city (Aristide Demetriade Street, Pictor Ion Zaicu Street, Meleție Drăghici Street, Andrei Mocioni Street, Nistrului Street);

- Green spaces between apartment blocks - 1.761 ha - they have been selected 9 green spaces between apartment blocks in the central area of the city. 
Current Trends in Natural Sciences

Vol. 9, Issue 17, pp. 257-265, 2020

https://doi.org/10.47068/ctns.2020.v9i17.032

Current Trends in Natural Sciences (on-line)

ISSN: 2284-953X

ISSN-L: 2284-9521
Current Trends in Natural Sciences (CD-Rom)

ISSN: 2284-9521 ISSN-L: 2284-9521

At the level of Timisoara municipality, total analyzed green spaces were: 47.519 ha

Table 1. The surface of the green spaces at the level of Timişoara agglomeration (https://www.primariatm.ro/uploads/files/comunicate net_2019/Plan_calitate aer_PM10.pdf)

\begin{tabular}{|c|c|c|}
\hline \multirow{2}{*}{ Types of green spaces } & Area (ha) & square feet/inhabitant \\
\cline { 2 - 3 } & Year 2018 & Year 2018 \\
\hline Parks & 92.209 & 0.51 \\
\hline Squares & 15.76 & 10.566 \\
\hline Green street spaces and blocks & 332.829 & 0.95 \\
\hline The forest curtain & 30.00 & 1.61 \\
\hline The Green Forest & 50.70 & 0.054 \\
\hline Playgrounds & 1.72 & 0.044 \\
\hline Ecological car parks & 1.4 & 16.664 \\
\hline TOTAL & 524.62 & \\
\hline
\end{tabular}

In this paper we started from the hypothesis according to which: The dispersion of the suspended particle concentrations PM10 at the level of Timişoara Agglomeration, can be reduced by the retention capacity of the green infrastructure?

We propose a methodology to highlight the benefits of the green spaces applied at the level of Timişoara Agglomeration, in which is used the internal variability of the green spaces (plant species, tree height, tree density) correlated with the spatial analysis of the dispersion of the suspended particle concentrations PM10, to highlight by a theoretical model the absorption of particles.

The retention capacity differs depending on the tree species as well as their density (Chen et al. 2019).

In order to estimate the retention capacity of the green infrastructure, the following steps were completed (Figure 1):

1. Calculation of retention capacity for PM10 (mg/individual/year), using:

- PM10 captured/leaf area (mg cm${ }^{-2} /$ year) for the species Quercus sp. Pinus sp. Salix sp. Tilia sp. Acer sp. Populus sp (Zhang et al. 2017 ; Chen et al. 2019)

- Leaf area $\mathrm{m}^{2} /$ individual for the species Quercus sp. Pinus sp. Salix sp. Tilia sp. Acer sp. Populus sp (Karlik and McKay, 2002)

2. Calculation of retention capacity for PM10 (tons/individual/year), using the retention capacity calculated on point 1 ;

3. Calculation of retention capacity for PM10 (tons/hectare-GI/year), using:

- Species determination using images published in Google Earth Photos

- Average density (number individuals/hectare-GI) (at the level of the analyzed green spaces density was estimated by counting the individuals for each species analyzed using the Google Earth Spatial)

- Retention capacity for PM10 (tons/individual/year), calculated on point 2

4. Calculation of total retention capacity/park, using: 
- Surface of green spaces (From the Open Street Map database, the green spaces at the level of the Timisoara Agglomeration were exported, subsequently in the analysis being calculated the surface of the green spaces for 27 central areas)

- Retention capacity for PM10 (tons/hectare-GI/year), calculated on point 3

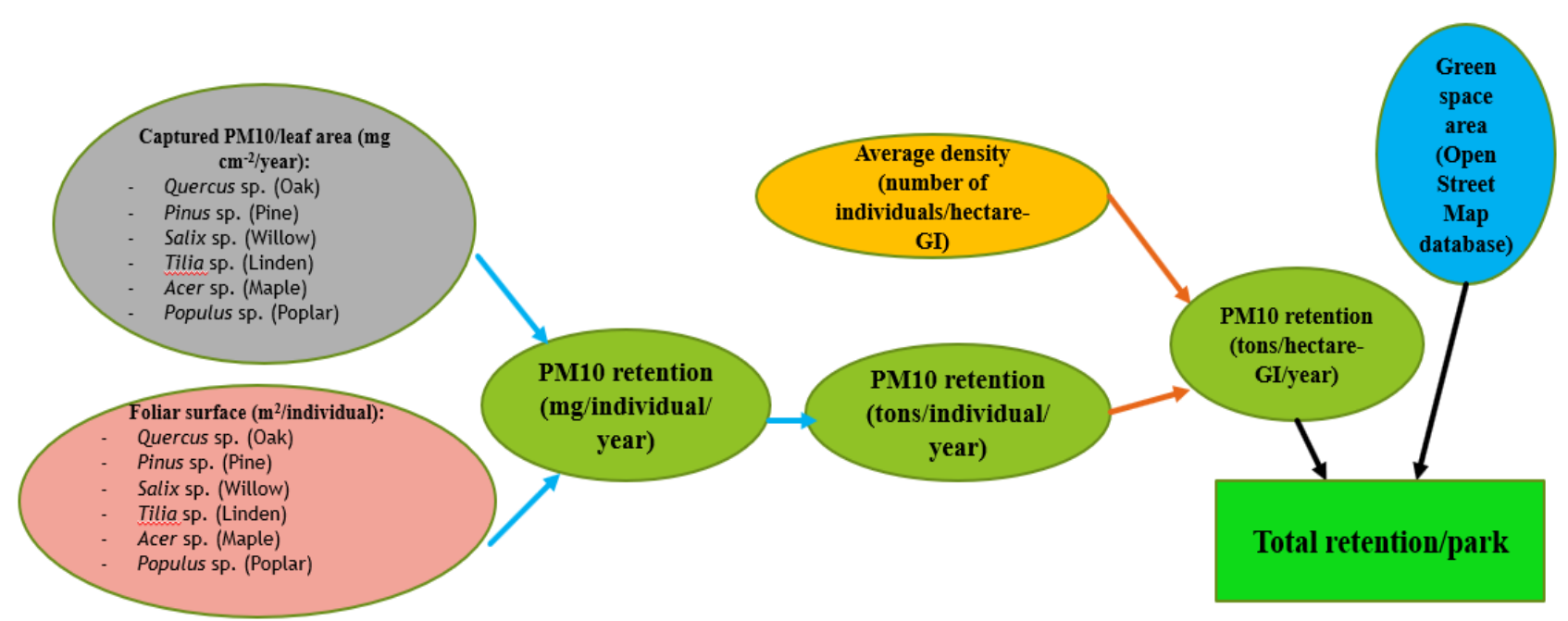

Figure 1. Calculation methodology to highlight the benefits of green spaces

\section{RESULTS AND DISCUSSIONS}

In the analysis stage of the internal variability of green spaces (Stage I), the following results were obtained: the density of the analyzed individuals was higher in the case of parks (Quercus sp.: 1 individual - 12 individuals, Pinus sp.: 12 individuals - 49 individuals, Salix sp.: 0 individuals - 16 individuals, Tilia sp.: 3 individuals - 17 individuals, Acer sp.: 1 individual - 27 individuals, Populus sp.: 3 individuals - 21 individuals) and smaller in the case of green spaces between apartment blocks (Quercus sp.: 0 individuals - 1 individual, Pinus sp.: 2 individuals - 8 individuals, Salix sp.: 0 individuals, Tilia sp.: 0 individuals - 3 individuals, Acer sp.: 0 individuals, Populus sp.: 0 individuals - 7 individuals) (Table 2).

Taking into account the density of the species (Table 2) as well as the retention capacity/individual (Figure 1), in Table 3 the retention capacity/hectare was calculated for the individuals of Quercus sp., Pinus sp., Salix sp., Tilia sp., Acer sp., Populus sp..Thus the highest retention capacities/hectare were for Pinus sp. (21.760 kg), Acer sp. (2.643 kg) and Tilia sp. (1.969 kg).

In the spatial analysis stage (Stage II) of the dispersion of the suspended particle concentrations PM10, the following results were obtained:

The retention capacity/year varies depending on the analyzed area (Figure 2):

- For areas between 0.125 - 3.369 ha, the retention capacity (\%)/year varies between $0.01 \%$ $2.89 \%$ (low retention), within these areas being included parks, street green spaces and green spaces between apartment blocks;

- For areas between 3.863 - 4.350 ha, the retention capacity (\%)/year varies between $5.67 \%$ $8 \%$ (medium retention), within these areas being included only parks;

- For areas of approximately 6 ha, the retention capacity (\%)/year can reach $10.39 \%$ (high retention), within these areas being included also parks. 
Table 2. Species density for analyzed green spaces

\begin{tabular}{|c|c|c|c|c|c|c|c|}
\hline Quercus sp. & Pinus sp. & Salix sp. & Tilia sp. & Acer sp. & Populus sp. & Area (ha) & $\begin{array}{c}\text { Green space } \\
\text { category }\end{array}$ \\
\hline 3 & 11 & 0 & 2 & 3 & 11 & 1.48 & Street green spaces \\
\hline 4 & 19 & 3 & 2 & 6 & 16 & 1.35 & Street green spaces \\
\hline 1 & 2 & 0 & 0 & 0 & 0 & 0.25 & $\begin{array}{l}\text { Green spaces between } \\
\text { apartment blocks }\end{array}$ \\
\hline 12 & 39 & 6 & 17 & 14 & 21 & 5.99 & Parks \\
\hline 0 & 2 & 0 & 1 & 0 & 0 & 0.13 & $\begin{array}{l}\text { Green spaces between } \\
\text { apartment blocks }\end{array}$ \\
\hline 0 & 8 & 0 & 3 & 0 & 7 & 0.24 & $\begin{array}{l}\text { Green spaces between } \\
\text { apartment blocks }\end{array}$ \\
\hline 0 & 38 & 5 & 4 & 2 & 2 & 2.36 & Street green spaces \\
\hline 0 & 8 & 0 & 2 & 0 & 1 & 0.21 & $\begin{array}{l}\text { Green spaces between } \\
\text { apartment blocks }\end{array}$ \\
\hline 0 & 4 & 0 & 2 & 0 & 2 & 0.19 & $\begin{array}{l}\text { Green spaces between } \\
\text { apartment blocks }\end{array}$ \\
\hline 1 & 7 & 0 & 2 & 0 & 0 & 0.24 & $\begin{array}{l}\text { Green spaces between } \\
\text { apartment blocks }\end{array}$ \\
\hline 0 & 3 & 0 & 2 & 0 & 1 & 0.13 & $\begin{array}{l}\text { Green spaces between } \\
\text { apartment blocks }\end{array}$ \\
\hline 0 & 8 & 0 & 3 & 0 & 7 & 0.24 & $\begin{array}{l}\text { Green spaces between } \\
\text { apartment blocks }\end{array}$ \\
\hline 2 & 18 & 1 & 7 & 5 & 3 & 1.33 & Parks \\
\hline 3 & 12 & 1 & 4 & 1 & 8 & 0.58 & Parks \\
\hline 1 & 24 & 0 & 3 & 2 & 2 & 1.68 & Parks \\
\hline 0 & 5 & 0 & 1 & 0 & 1 & 0.13 & $\begin{array}{l}\text { Green spaces between } \\
\text { apartment blocks }\end{array}$ \\
\hline 4 & 31 & 5 & 6 & 27 & 21 & 3.86 & Parks \\
\hline 8 & 49 & 2 & 12 & 9 & 11 & 4.35 & Parks \\
\hline 8 & 41 & 11 & 6 & 12 & 6 & 4.20 & Parks \\
\hline 2 & 19 & 17 & 2 & 3 & 6 & 2.90 & Street green spaces \\
\hline 4 & 38 & 16 & 11 & 7 & 8 & 4.27 & Parks \\
\hline 2 & 19 & 0 & 7 & 4 & 3 & 2.57 & Parks \\
\hline 3 & 19 & 5 & 9 & 5 & 8 & 1.66 & Parks \\
\hline 4 & 22 & 19 & 6 & 3 & 5 & 1.38 & Street green spaces \\
\hline 7 & 29 & 2 & 6 & 8 & 8 & 3.37 & Parks \\
\hline 1 & 9 & 0 & 2 & 1 & 8 & 0.62 & Street green spaces \\
\hline 2 & 28 & 2 & 3 & 6 & 27 & 1.76 & Street green spaces \\
\hline
\end{tabular}

Regarding the exposure of green spaces to PM10 concentrations $(24 \mathrm{~h})$, we can highlight that the retention capacities (\%/year) between $0.01 \%$ - 2.84\%, 5.67\% - 8\% and $10.39 \%$ were associated with a low exposure, while a retention capacity of $1.02 \%$ was associated with a medium exposure, noting that these retention capacities are below the accepted exposure limit (Figure 3).

And in the areas that are above the limit value $\left(\mathrm{VL}=50 \mu \mathrm{g} / \mathrm{m}^{3}\right)$, there are retention capacities of $1,44 \%$ and $2,89 \%$, noting that these retention capacities are above the accepted exposure limit.

Of the total number of green spaces analyzed, 25 green spaces (street green spaces: Aristide Demetriade Street, Pictor Ion Zaicu Street, Nistrului Street; parks: Botanical Park, Central Park, Cathedral Park, Justice Park, Civic Park, Children's Park, the park next to the Student Complex; 


\section{Current Trends in Natural Sciences}

Vol. 9, Issue 17, pp. 257-265, 2020

https://doi.org/10.47068/ctns.2020.v9i17.032

Current Trends in Natural Sciences (on-line)

ISSN: 2284-953X

Current Trends in Natural Sciences (CD-Rom)

ISSN: 2284-9521

ISSN-L: 2284-9521 ISSN-L: 2284-9521

9 green spaces between apartment blocks located in the central area of the city) were located below the accepted exposure limit and 2 green spaces (street green spaces: Meleție Drăghici Street, Andrei Mocioni Street; parks: People's Park) were located above the accepted exposure limit (Figure 3).

In Figure 4 it can be seen that areas with a higher number of green spaces and high density of individuals is not exceeded the accepted exposure limit, while areas with a lower number of green spaces and low density of individuals may exceed the accepted exposure limit.

Table 3. Species retention capacity (kg/year)/hectare

\begin{tabular}{|c|c|c|c|c|c|c|}
\hline Quercus sp. & Pinus sp. & Salix sp. & Tilia sp. & Acer sp. & Populus sp. & Green space category \\
\hline 0.06 & 0.4675 & 0 & 0.0315 & 0.0672 & 0.004136 & Street green spaces \\
\hline 0.08 & 0.8075 & 0.00144 & 0.0315 & 0.1344 & 0.006016 & Street green spaces \\
\hline 0.02 & 0.085 & 0 & 0 & 0 & 0 & $\begin{array}{l}\text { Green spaces between } \\
\text { apartment blocks }\end{array}$ \\
\hline 0.24 & 1.6575 & 0.00288 & 0.26775 & 0.3136 & 0.007896 & Parks \\
\hline 0 & 0.085 & 0 & 0.01575 & 0 & 0 & $\begin{array}{l}\text { Green spaces between } \\
\text { apartment blocks }\end{array}$ \\
\hline 0 & 0,34 & 0 & 0.04725 & 0 & 0.002632 & $\begin{array}{l}\text { Green spaces between } \\
\text { apartment blocks }\end{array}$ \\
\hline 0 & 1.615 & 0.0024 & 0.063 & 0.0448 & 0.000752 & Street green spaces \\
\hline 0 & 0.34 & 0 & 0.0315 & 0 & 0.000376 & $\begin{array}{l}\text { Green spaces between } \\
\text { apartment blocks }\end{array}$ \\
\hline 0 & 0.17 & 0 & 0.0315 & 0 & 0.000752 & $\begin{array}{l}\text { Green spaces between } \\
\text { apartment blocks }\end{array}$ \\
\hline 0.02 & 0.2975 & 0 & 0.0315 & 0 & 0 & $\begin{array}{l}\text { Green spaces between } \\
\text { apartment blocks }\end{array}$ \\
\hline 0 & 0.1275 & 0 & 0.0315 & 0 & 0.000376 & $\begin{array}{l}\text { Green spaces between } \\
\text { apartment blocks }\end{array}$ \\
\hline 0 & 0.34 & 0 & 0.04725 & 0 & 0.002632 & $\begin{array}{l}\text { Green spaces between } \\
\text { apartment blocks }\end{array}$ \\
\hline 0.04 & 0.765 & 0.00048 & 0.11025 & 0.112 & 0.001128 & Parks \\
\hline 0.06 & 0.51 & 0.00048 & 0.063 & 0.0224 & 0.003008 & Parks \\
\hline 0.02 & 1.02 & 0 & 0.04725 & 0.0448 & 0.000752 & Parks \\
\hline 0 & 0.2125 & 0 & 0.01575 & 0 & 0.000376 & $\begin{array}{l}\text { Green spaces between } \\
\text { apartment blocks }\end{array}$ \\
\hline 0.08 & 1.3175 & 0.0024 & 0.0945 & 0.6048 & 0.007896 & Parks \\
\hline 0.16 & 2.0825 & 0.00096 & 0.189 & 0.2016 & 0.004136 & Parks \\
\hline 0.16 & 1.7425 & 0.00528 & 0.0945 & 0.2688 & 0.002256 & Parks \\
\hline 0.04 & 0.8075 & 0.00816 & 0.0315 & 0.0672 & 0.002256 & Street green spaces \\
\hline 0.08 & 1.615 & 0.00768 & 0.17325 & 0.1568 & 0.003008 & Parks \\
\hline 0.04 & 0.8075 & 0 & 0.11025 & 0.0896 & 0.001128 & Parks \\
\hline 0.06 & 0.8075 & 0.0024 & 0.14175 & 0.112 & 0.003008 & Parks \\
\hline 0.08 & 0.935 & 0.00912 & 0.0945 & 0.0672 & 0.00188 & Street green spaces \\
\hline 0.14 & 1.2325 & 0.00096 & 0.0945 & 0.1792 & 0.003008 & Parks \\
\hline 0.02 & 0.3825 & 0 & 0.0315 & 0.0224 & 0.003008 & Street green spaces \\
\hline 0.04 & 1.19 & 0.00096 & 0.04725 & 0.1344 & 0.010152 & Street green spaces \\
\hline 1.440 & 21.760 & 0.046 & 1.969 & 2.643 & 0.073 & Total \\
\hline
\end{tabular}



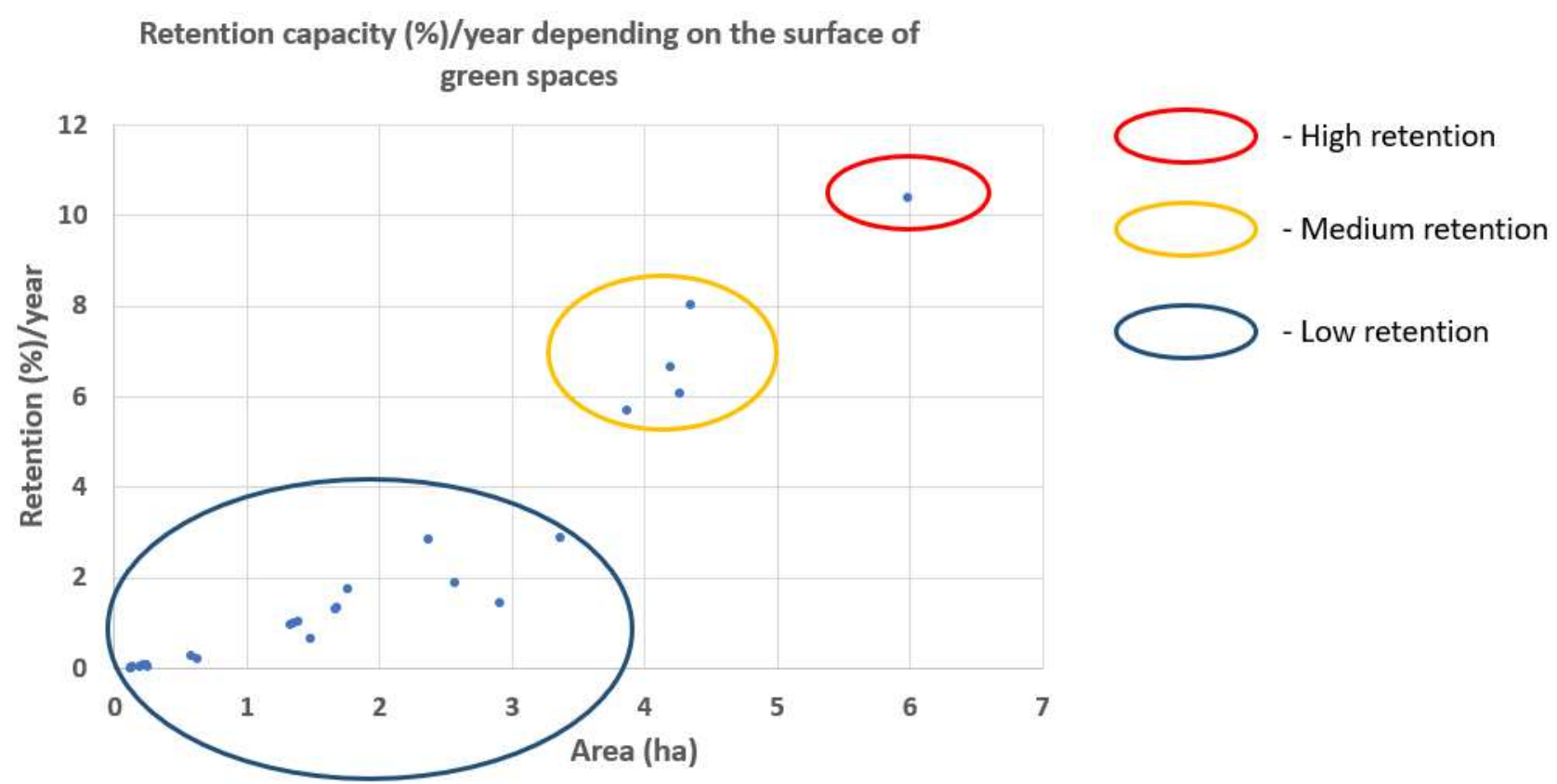

Figure 2. Retention capacity (\%)/year depending on the surface of green spaces

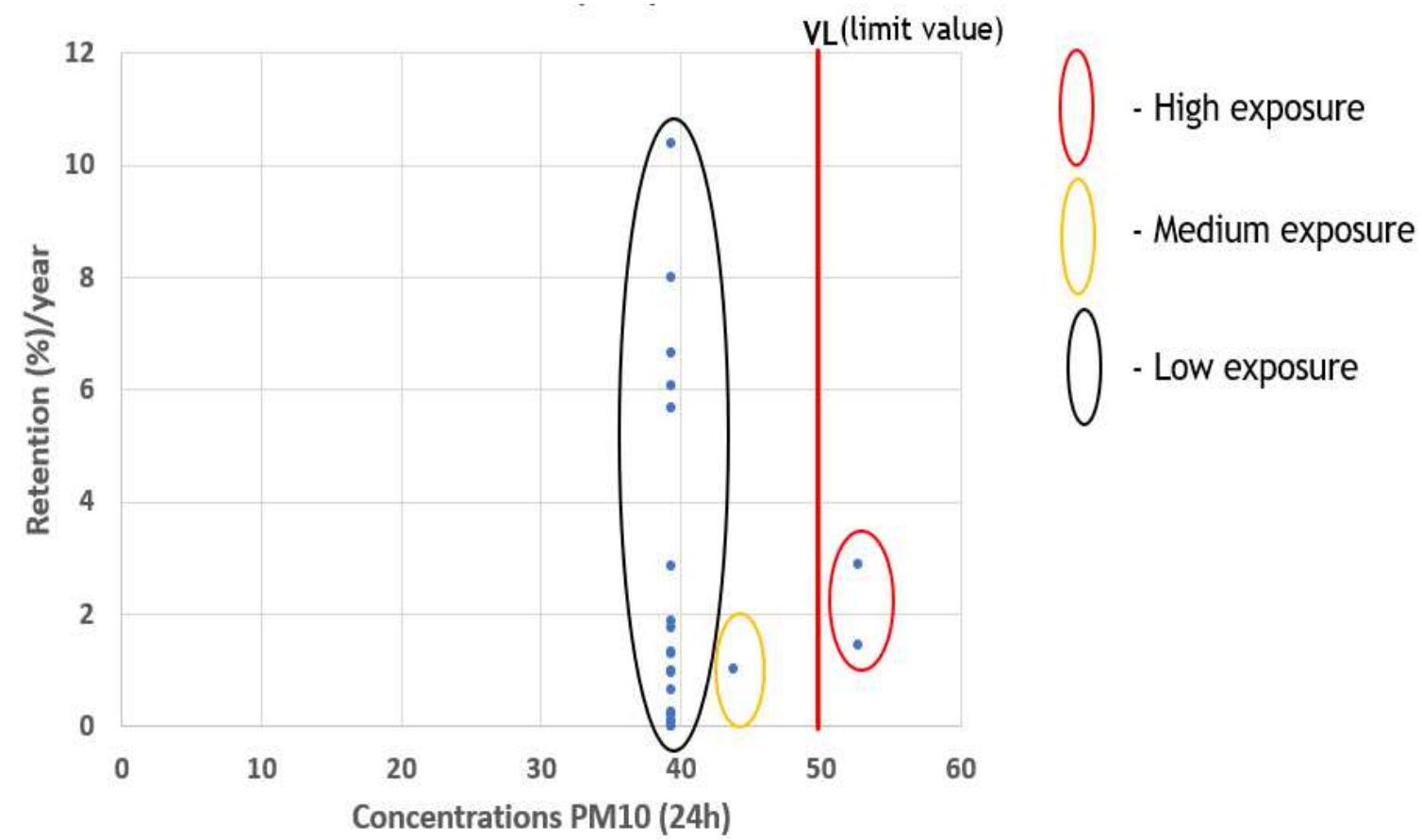

Figure 3. Exposure to concentrations PM10 (24h) in relation to the retention capacity

Thus, from the integrated analysis of the data from the two stages, it is observed that the parks of over 4 ha (Central Park, Cathedral Park, Children's Park) that have a high density of individuals can have a retention capacity of PM10 suspended particles of approximately $6 \%$.

Such estimates are very difficult to validate without a sustained basic research program. Testing and validation of results requires in-depth studies conducted in the medium and long term. 


\begin{tabular}{lcr}
\hline & $\begin{array}{c}\text { Current Trends in Natural Sciences } \\
\text { Vol. 9, Issue 17, pp. 257-265, 2020 }\end{array}$ \\
& $\begin{array}{c}\text { Current Trends in Natural Sciences (CD-Rom) } \\
\text { ISSN: 2284-9521 }\end{array}$ \\
\cline { 2 - 2 } Current Trends in Natural Sciences (on-line) & ISSN-L: 2284-9521 \\
ISSN: 2284-953X & & ISSN-L: 2284-9521 \\
ISS/10.47068/ctns.2020.v9i17.032
\end{tabular}

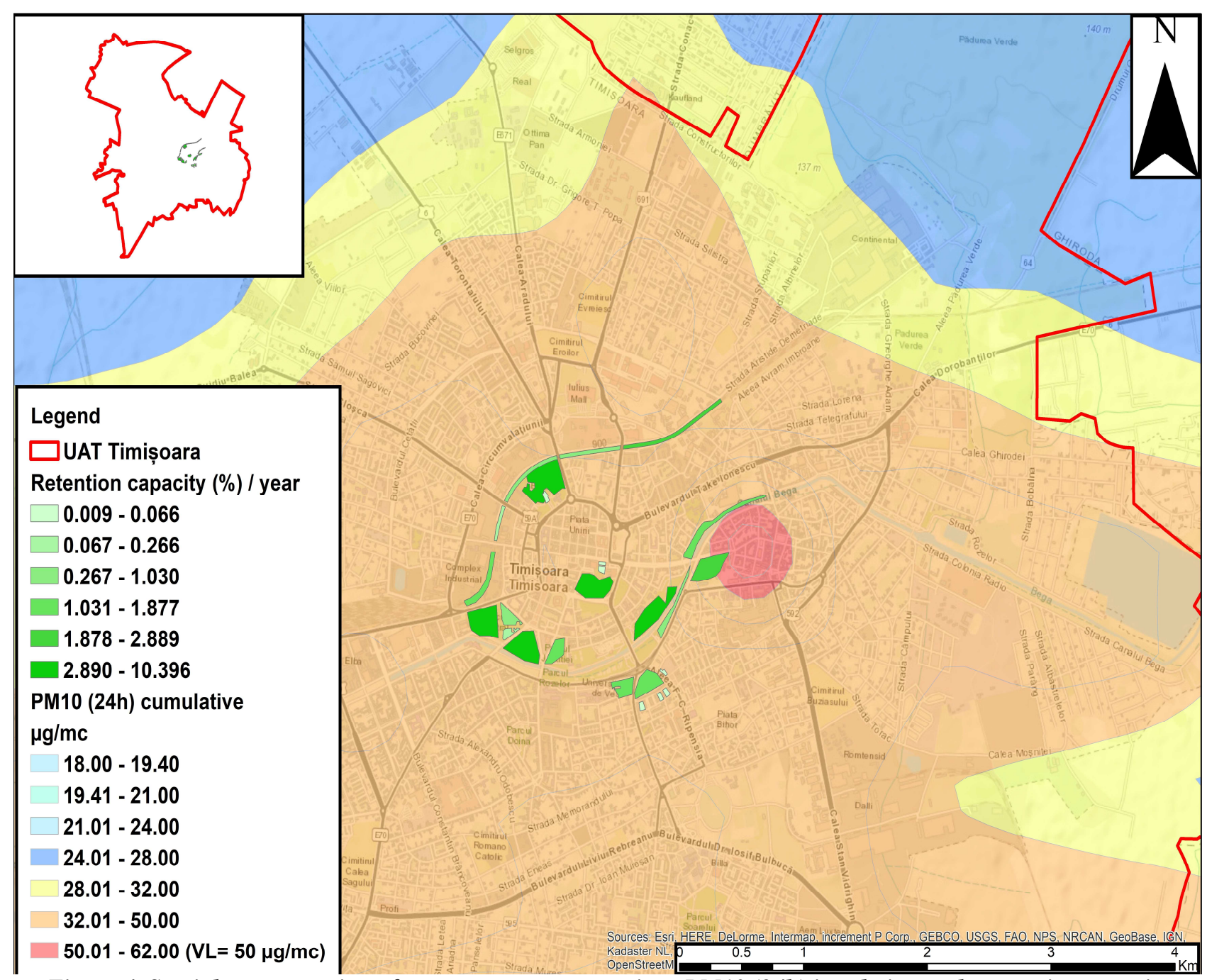

Figure 4. Spatial representation of exposure to concentrations PM10 (24h) in relation to the retention capacity

\section{CONCLUSIONS}

Following the calculations, it was estimated that the green infrastructure has a minimum retention capacity of approximately $0.01 \%$ and a maximum of $10.39 \%$ of the concentration of PM10 suspended particles, to which the green infrastructure is exposed.

The retention capacity of $10.39 \%$ is close to the limit value $\left(\mathrm{VL}=50 \mu \mathrm{g} / \mathrm{m}^{3}\right)$, and in the areas above the limit value it is a retention capacity of $2.89 \%$ compared to the exposure concentration.

The green infrastructure has a capacity to retain and reduce the dispersion of suspended particles and treats an effect and does not address the cause (emission source).

These analyzes are indispensable in the process of prioritizing measures to reduce and compensate for the negative effects of air pollution within the quality plans at local level, thus measures aimed at reducing at source as well as those to limit dispersion with reduction by retention without being followed by removal (eg by washing, fixing the substrate, soil), in order not to be remobilized, must be applied complementary in order to have an immediate effect of improving air quality with a positive impact on the health of exposed persons. 


\section{ACKNOWLEDGEMENTS}

Thanks to the Timişoara City Hall and S.C Multidimension S.R.L for making available the Air Quality Plan for PM10 in the Timişoara Agglomeration.

We mention that the article was made using non-confidential data presented in the Air Quality Plan for PM10 proposed in public debate on the website of Timisoara City Hall.

\section{REFERENCES}

Bealey, W.J., McDonald, A.G., Nemitz, E., Donovan, R., Dragosits, U., Duffy, T.R., Fowler, D. (2006). Estimating the reduction of urban PM10 concentrations by trees within an environmental information system for planners, Journal of Environmental Management, 85, 44 - 58.

Benedict, M.A., McMahon, E.T. (2006). Green Infrastructure Linking Landscapes and Communities, Landscape Ecology (Vol.22, pp. 797 - 798). City: Washington, DC, USA.

Chen, H., Kaiyang, Q., Richard, P. (2019). Reduction of urban traffic-related particulate matter-leaf trait matters, Environmental Science and Pollution Research, 27, 5825 - 5844.

Hewitt, C.N., Ashworth, K., MacKenzie, A.R. (2019). Using green infrastructure to improve urban air quality (GI4AQ), Ambio, 49, 62 - 73 .

Nowak, D.J., Crane, D.E., Stevens, J.C. (2006). Air pollution removal by urban trees and shrubs in the United States, Urban Forestry \& Urban Greening, 4(3-4), 115 - 123.

Nowak, D.J., Heisler M.G. (2010). Air Quality Effects of Urban Trees and Parks, 6 - 34, Retrieved May 01, 2020, from https://www.nrpa.org/globalassets/research/nowak-heisler-summary.pdf.

Zhang, W., Wang, B., Niu, X. (2017). Relationship between Leaf Surface Characteristics and Particle Capturing Capacities of Different Tree Species in Beijing, Forests, 8(3), 92, $5-8$.

Karlik, J.F., McKay, A.H. (2002). Leaf Area Index, Leaf Mass Density, and Allometric Relationships Derived From Harvest of Blue Oaks in a California Oak Savanna, In B. Richard, Standiford et al, tech. editor. Proceedings of the Fifth Symposium on Oak Woodlands: Oaks in California"s Challenging Landscape. Gen. Tech. Rep. PSWGTR-184, U.S. Department of Agriculture: (pp. 719-729). City: Albany, CA.

*** Air quality in Europe - 2019 report, (2019). European Environment Agency, 10 - 75, Retrieved April 20, 2020, from https://www.eea.europa.eu/publications/air-quality-in-europe-2019.

*** planul de calitate a aerului pentru pm10 în aglomerarea Timişoara perioada 2020-2024 [Air quality plan for pm10 in Timişoara agglomeration period 2020-2024], Retrieved March 21, 2020, from https://www.primariatm.ro/uploads/files/comunicate net_2019/Plan_calitate_aer_PM10.pdf.

*** Green spaces database, Retrieved April 01, 2020, from https://www.openstreetmap.org/\#map=12/45.7577/21.2414;

*** Estimation of average density of tree species, from https://www.google.com/intl/ro/earth/.

*** Species determination using images published, from https://www.google.com/intl/ro/earth/.

*** Benefits of Green Infrastructure, Retrieved April 02, 2020, from https://www.epa.gov/green-infrastructure/benefitsgreen-infrastructure. 